\title{
Responses of cancer cells with wild-type or tyrosine kinase domain-mutated epidermal growth factor receptor (EGFR) to EGFR-targeted therapy are linked to downregulation of hypoxia-inducible factor-I $\alpha$ \\ Yang Lu, Ke Liang, Xinqun Li and Zhen Fan*
}

Address: Department of Experimental Therapeutics, The University of Texas M. D. Anderson Cancer Center, Houston, Texas 77030, USA

Email: Yang Lu - ylu@mdanderson.org; Ke Liang - kliang@mdanderson.org; Xinqun Li - xinquli@mdanderson.org;

Zhen Fan*-zfan@mdanderson.org

* Corresponding author

Molecular Cancer 2007, 6:63 doi:10.1/86/1476-4598-6-63

This article is available from: http://www.molecular-cancer.com/content/6/1/63

(C) 2007 Lu et al; licensee BioMed Central Ltd.

This is an Open Access article distributed under the terms of the Creative Commons Attribution License (http://creativecommons.org/licenses/by/2.0), which permits unrestricted use, distribution, and reproduction in any medium, provided the original work is properly cited.

\begin{abstract}
Background: Searching for novel molecular markers that dependably predict or indicate responses of human cancer cells to epidermal growth factor receptor (EGFR)-targeted therapy is strongly warranted. The purpose of the current study was to evaluate hypoxia-inducible factor-I $\alpha$ $(H I F-I \alpha)$ as a novel response marker compared with previously explored markers following treatment with an EGFR-blocking monoclonal antibody (cetuximab) and a small-molecule EGFR tyrosine kinase inhibitor (gefitinib) in a group of cancer cell lines containing wild-type or tyrosine kinase domain-mutated EGFR.

Results: We found that, compared with previously studied response markers, including EGFR per se and three EGFR downstream signal molecules (ERK, Akt, and STAT3), which showed variable post-treatment changes in levels of phosphorylation and no consistent link of the changes to therapeutic responses, HIF-I $\alpha$ showed a selective decrease in protein levels only in responsive cell lines. To demonstrate a critical role of HIF-I $\alpha$ downregulation by EGFR-targeted treatment, we introduced a constitutively expressed HIF-I $\alpha$ mutant (HIF-I $\alpha / \Delta O D D)$ that is resistant to cetuximab-induced downregulation in a cetuximab-responsive cell line (A43I); we found that the HIF-I $\alpha / \Delta O D D$-transfected cells remained sensitive to cetuximab-induced inhibition of Akt and ERK phosphorylation but were remarkably less responsive to cetuximab-induced growth inhibition compared with corresponding control cells.
\end{abstract}

Conclusion: Our data indicates that downregulation of HIF-I $\alpha$ is associated with positive therapeutic responses of cancer cells to EGFR-targeted therapy and suggest further investigation using HIF- $I \alpha$ as an indicator of tumor response to EGFR-targeted therapy in preclinical studies and in the clinical setting.

\section{Background}

Epidermal growth factor receptor (EGFR) has been implicated in the development and progression of a diverse type of solid tumors. Over the past two decades, experimental cancer therapies targeting EGFR have been studied extensively [1-4]. Recent clinical studies have found that 
targeting EGFR with receptor-blocking monoclonal antibodies such as cetuximab and panitumumab, or with small-molecule EGFR tyrosine kinase inhibitors (TKIs) such as gefitinib and erlotinib, is effective against several types of solid tumors [5-9]. TKI is particularly effective against a subset of non-small cell lung cancers (NSCLCs) that have several somatic mutations in the EGFR tyrosine kinase domain [10-12]. However, many patients do not experience favorable responses to EGFR-targeted therapy, regardless of positive or even high EGFR expression in their tumors [5-9].

Accumulating evidence indicates that the response of cancer cells to EGFR-targeted therapy is a complex process that can be affected by multiple intrinsic and extrinsic resistance mechanisms. Currently, there is a lack of dependable response markers that can objectively predict or indicate therapeutic responses of patients to EGFR-targeted therapies. Exploration of the genetic and biochemical determinants of response to the therapy not only may help identifying patients who would benefit from EGFRtargeted therapy but also may help in the design of co-targeting strategies to improve treatment effectiveness in patients who do not experience an optimal response to EGFR-targeted therapy alone.

We and others recently found that treatment of responsive cancer cells with cetuximab or gefitinib downregulated the levels of hypoxia-inducible factor- $1 \alpha$ (HIF-1 $\alpha$ ) under both normoxic and hypoxic conditions $[13,14]$. HIF- $1 \alpha$ is a component of the HIF-1 heterodimer that is an important transcription factor for the expression of a wide array of genes involved in a variety of cellular functions, including cell cycle traversal, angiogenesis, anti-apoptotic activity, and oxygen homeostasis [15,16]. HIF- $1 \alpha$ is overexpressed in a large number of human tumors, and its overexpression correlates with poor prognosis and treatment failure $[15,16]$. HIF- $1 \alpha$ has a very quick turnover rate in normoxia due to an oxygen-dependent ubiquitination and degradation process of the protein $[15,16]$ and is thus constantly replenished by newly synthesized protein in a phosphatidylinositol 3-kinase signaling pathwaydependent manner that may be activated by multiple growth factors or oncogenes [17-22]. This existing knowledge suggests that HIF-1 $\alpha$ may be a good indicator of tumor response to EGFR-targeted therapy, but to date no studies have investigated this possibility.

In the present study, we used a group of cancer cell lines with overexpressed EGFR or tyrosine kinase domainmutated EGFR to determine the association of the cellular responses with response markers to EGFR-targeted therapy with cetuximab and gefitinib. Two recent studies evaluated biochemical changes in cell signaling after cetuximab and gefitinib treatment in association with therapeutic responses of several EGFR wild-type and tyrosine kinase domain-mutated cancer cell lines [23,24]. Amann $e t$ al. found that both agents induced apoptosis in HCC827 cells (an NSCLC cell line with a 746E-750A inframe deletion) and that the IC50 (50\% inhibitory concentrations) of TKIs and cetuximab were more closely associated with the phosphorylation inhibition of extracellular signaling-related kinase (ERK) and Akt than with EGFR in HCC827, H1819, and H1299 cell lines [23]. Mukohara et al. found that gefitinib and cetuximab had similar effects on inhibiting the growth of NSCLC cells with wild-type EGFR (slight inhibition in A549 and H441 cells and moderate inhibition in H1666 cells) but that gefitinib was stronger than cetuximab in inhibiting EGFRmutated cell lines (H3255, DFCILU-011, and PC-9). In HCC827 cells, both gefitinib and cetuximab induced apoptosis, but gefitinib induced apoptosis to a greater extent than cetuximab [24].

We found in this study that post-treatment downregulation of HIF-1 $\alpha$ was more consistently associated with cellular response than were the biochemical changes of ERK and Akt or that of STAT3, another downstream signaling molecule commonly activated by EGFR. When we experimentally elevated HIF- $1 \alpha$ expression level by transfecting a constitutively expressed HIF- $1 \alpha$ mutant in A431 cells, we found marked resistance of the transfected cells to cetuximab treatment, despite their unchanged sensitivity to cetuximab-induced inhibition of ERK and Akt phosphorylation levels. Our data suggest that HIF- $1 \alpha$ is an effective molecular response marker for EGFR-targeted therapy and should be further tested in preclinical studies and in clinical trials.

\section{Results \\ Time- and dose-dependent anti-proliferative and apoptotic responses of cancer cells with wild-type and tyrosine kinase domain-mutated EGFR to cetuximab and gefitinib treatment}

Figure 1 shows the genetic and biochemical characteristics of the cell lines used in our study. Compared with the EGFR coding sequences in the GenBank, which originated from A431 cells, no mutations were found in the tyrosine kinase domain of EGFR in DiFi colorectal carcinoma cells (Fig. 1a). In contrast, HCC827 and HCC2279 NSCLC cells had a $\Delta$ E746-A750 deletion mutation, and H3255 and H1975 cells had an L858R point mutation. Figure 1b shows the levels of protein expression in the EGFR family, including EGFR (HER1), HER2, and HER3, and the levels of activation-specific phosphorylation of the three most common EGFR substrates, ERK, Akt, and STAT3. At baseline, HCC827, HCC2279, and H3255 cells expressed intermediate levels of EGFR, whereas A431 and DiFi cells expressed high levels. In contrast, H1975 cells expressed the lowest level of EGFR, which was barely detectable 
a
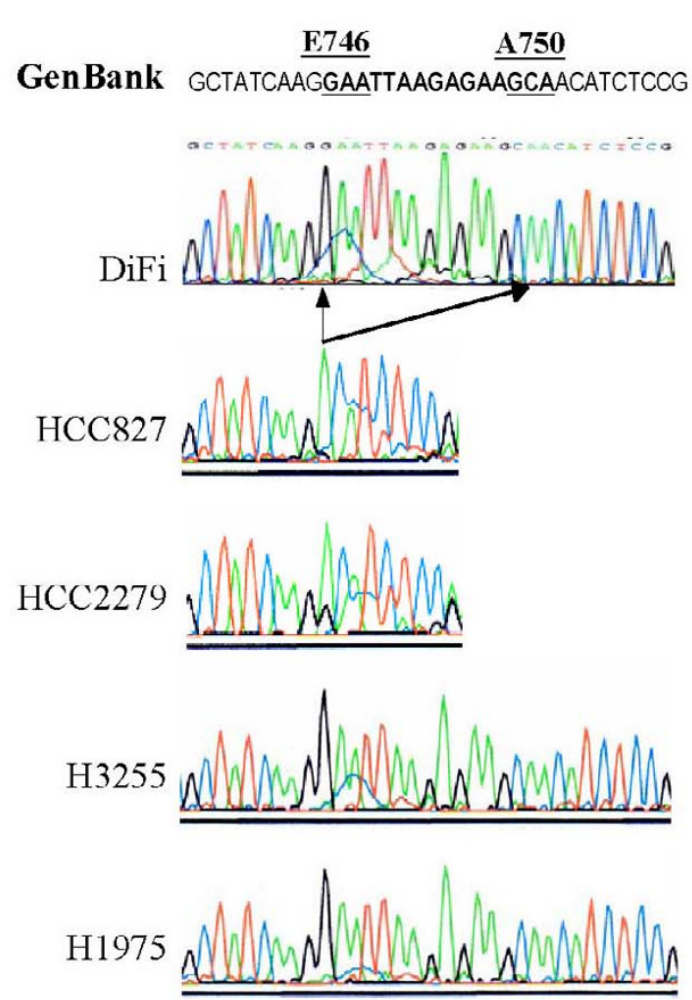

b

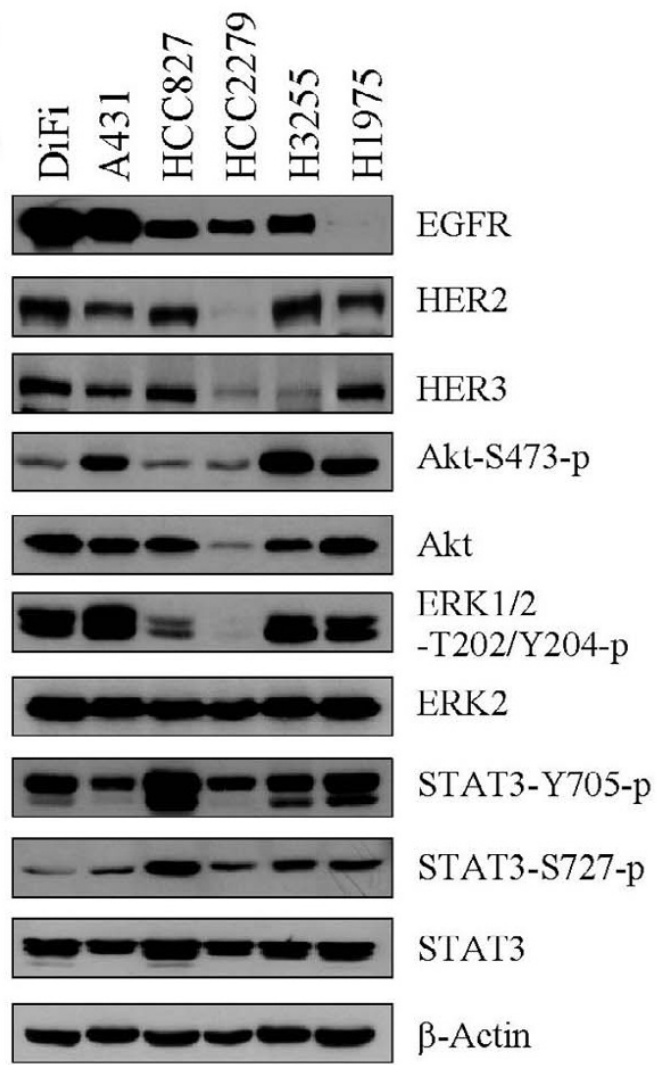

Figure I

Cancer cell lines with wild-type or tyrosine kinase domain-mutated EGFR. (a) PCR fragments from the indicated cell lines were compared with the wild-type sequence of EGFR. The black arrows indicate the codons E746 to A750, which are present in the EGFR in DiFi cells but have been deleted in HCC827 and HCC2279 cells. Codon L858R substitution in HI975 and H3255 cells is indicated by arrows. (b) Lysates from the indicated cell lines maintained in regular culture medium were prepared for Western blot analysis using antibodies directed against EGFR, HER2, and HER3, and antibodies directed against total and activationspecific phosphorylated downstream signaling molecules (ERK, Akt, and STAT3). The level of $\beta$-actin was used as a reference of lysate protein loading control of each cell line.

unless the film was overexposed. HER2 and HER3 were readily detectable in the cell lines except in H3255 cells (low in HER3) and HCC2279 cells (low in both HER2 and HER3). The basal levels of EGFR downstream signaling, shown by the levels of activation-specific phosphorylation of Akt, ERK, and STAT3, were not consistently associated with the HER family expression levels or EGFR sequence-coding status in a positive or negative manner among the cell lines.

Figure 2a shows the time-dependent responses of these individual cell lines to treatment with $10 \mathrm{nM}$ cetuximab or $0.5 \mu \mathrm{M}$ gefitinib for 4 days. Four cell lines (DiFi, HCC827, H3255, and A431) showed marked growth inhibition responses after cetuximab or gefitinib treatment, whereas HCC2279 and H1975 cells showed only moderate or poor growth inhibition. The degrees of growth inhibition of DiFi cells after cetuximab (10 nM) and gefitinib (0.5 $\mu \mathrm{M})$ treatments were comparable, but in A431 and HCC 827 cells more growth inhibition was induced by cetuximab than by gefitinib. In contrast, H3255 cells responded more strongly to gefitinib than to cetuximab: massive cell death was microscopically visible just a few hours after exposure to gefitinib, whereas the response of H3255 cells to cetuximab was slower and not evident until those cells had been exposed to the treatment overnight (data not shown). HCC2279 and H1975 cell lines demonstrated much less growth inhibition than did other cell lines in response to treatment with either agent. The growth rate of HCC2279 cells was much slower than that in the other cell lines, which may partly explain the moderate inhibitory effects of the agents on HCC2279 cell proliferation. H1975 cells, which also contain a second mutation (T790M) linked to gefitinib resistance [25], responded poorly to either agent. 
a

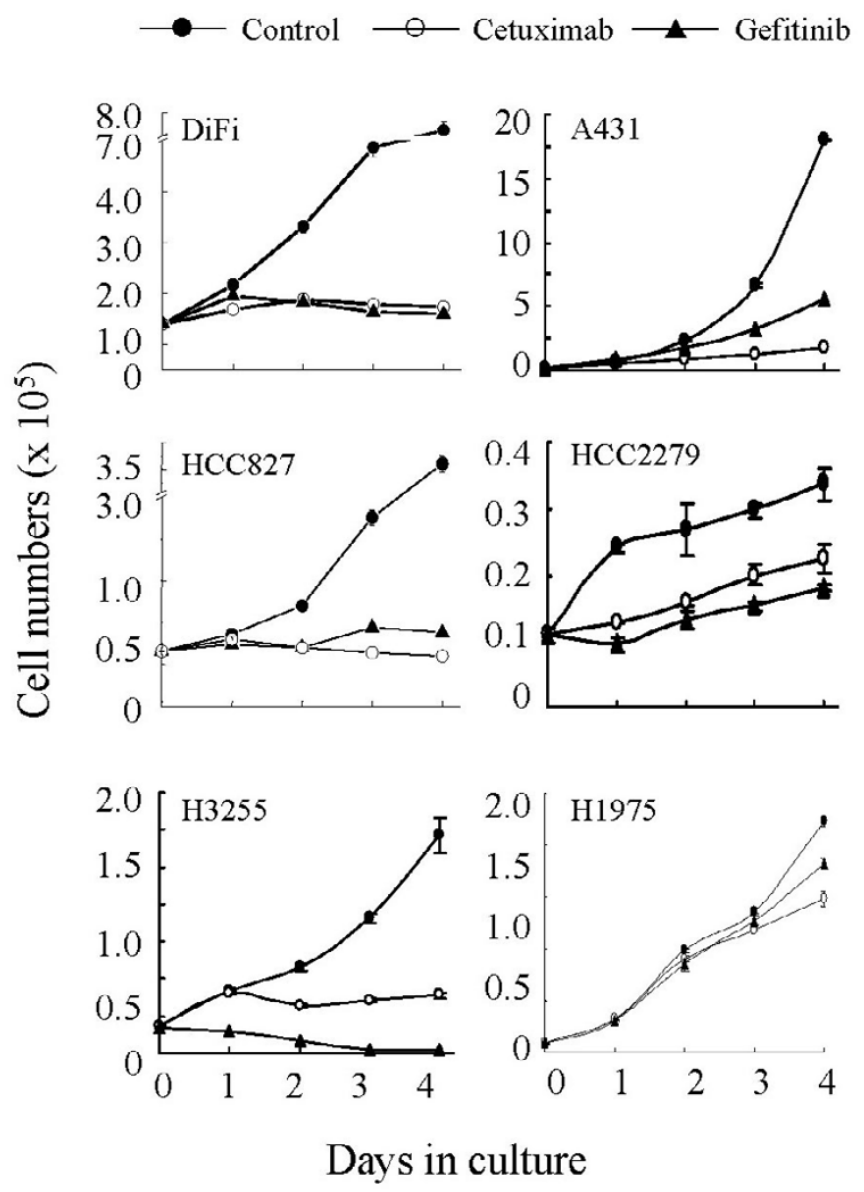

b

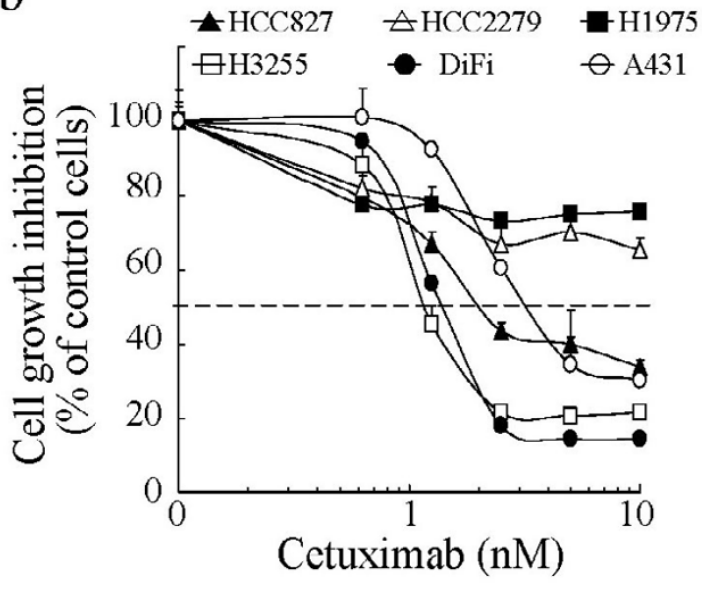

C

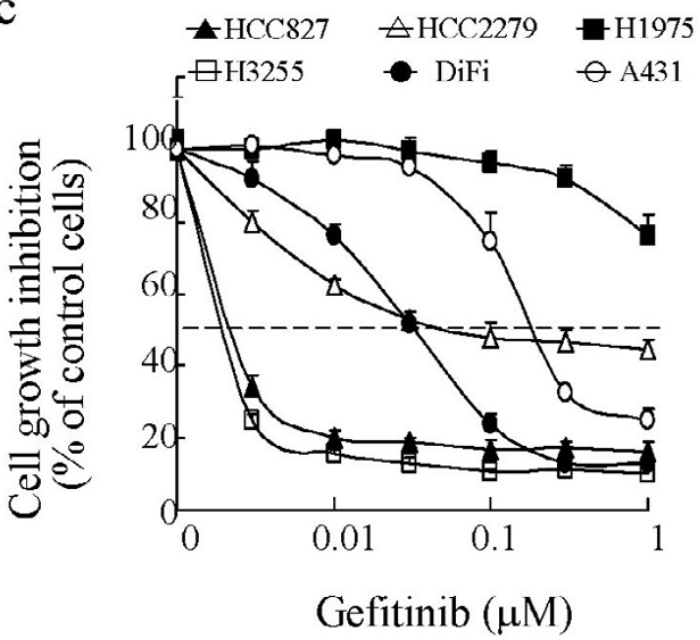

Figure 2

Dose- and time-dependent responses of wild-type EGFR and tyrosine kinase domain-mutated EGFR cells to cetuximab and gefitinib treatment. (a) Absolute cell numbers in each treatment group (control [DMSO]), $5 \mathrm{nM}$ cetuximab, and $0.5 \mu \mathrm{M}$ gefitinib, all in $0.5 \%$ FBS medium) were plotted against the duration of treatment. (b) The inhibition of cell proliferation after treatment with cetuximab was measured by an MTT assay and is shown as a percentage of the optical density value of control cells (untreated) for each concentration tested. (c) The inhibition of cell proliferation after treatment with gefitinib was measured as in (b) and is shown as a percentage of the optical density value of vehicle-treated cells (DMSO) for each concentration tested. Results are shown as the mean of five independent measurements, plus or minus the standard deviation (SD). The magnitude of some SDs was smaller than the symbol size; thus some bars do not appear in the figure.

Figure $2 \mathrm{~b}$ shows the simultaneous dose-dependent growth inhibition responses of the cell lines to treatment with serial dilutions of cetuximab for 72 hours. H3255 cells showed a dose-dependent response to cetuximab that was similar to that of DiFi cells, and HCC827 cells showed a response that was less sensitive than that of $\mathrm{DiFi}$ cells but better than that of A431 cells at lower doses ( 3 nM). The growth of HCC2279 and H1975 cells was minimally inhibited by cetuximab.

In contrast to the results of cetuximab treatment, two EGFR-mutated cell lines, HCC827 and H3255, were far more sensitive to lower $(<0.01 \mu \mathrm{M})$ concentrations of gefitinib than were DiFi and A431 cells (Fig. 2c). When the gefitinib concentration was $\geq 0.1 \mu \mathrm{M}$, DiFi cells exhibited responses comparable to those seen in HCC827 and H3255 cells, but this concentration was still lower than the doses required to produce similar growth inhibition in A431 cells. HCC2279 cells also responded to gefitinib treatment at lower concentrations compared with DiFi and A431 cells, but the maximal level of inhibition was less than that seen in DiFi and A431 cells. Unlike other cells, H1975 cells responded poorly to gefitinib, as reported by other investigators [25]. 
To determine whether cetuximab or gefitinib induced apoptosis in the cell lines, we used two independent apoptosis assays: an enzyme-linked immunosorbent assay to measure the cytoplasmic levels of histone-associated DNA fragments characteristic of apoptotic cells and a Western blot analysis to detect the proteolytic cleavage of poly(adenosine diphosphate-ribose) polymerase (PARP) (Fig. 3a and 3b). Clear evidence of apoptosis was found in three cell lines: DiFi, HCC827, and H3255. At the doses tested, gefitinib seemed to induce a higher cytoplasmic level of histone-associated DNA fragments than did cetuximab (Fig. 3a), but both agents had similar effects on PARP cleavage (Fig. 3b). DiFi cells contained a high basal level of cleaved PARP when cultured in low-serum medium, but the cleaved PARP fragment level clearly increased after treatment. Although cell proliferation was strongly inhibited, no clear sign of apoptosis was detected in A431 cells after treatment with cetuximab or gefitinib

a

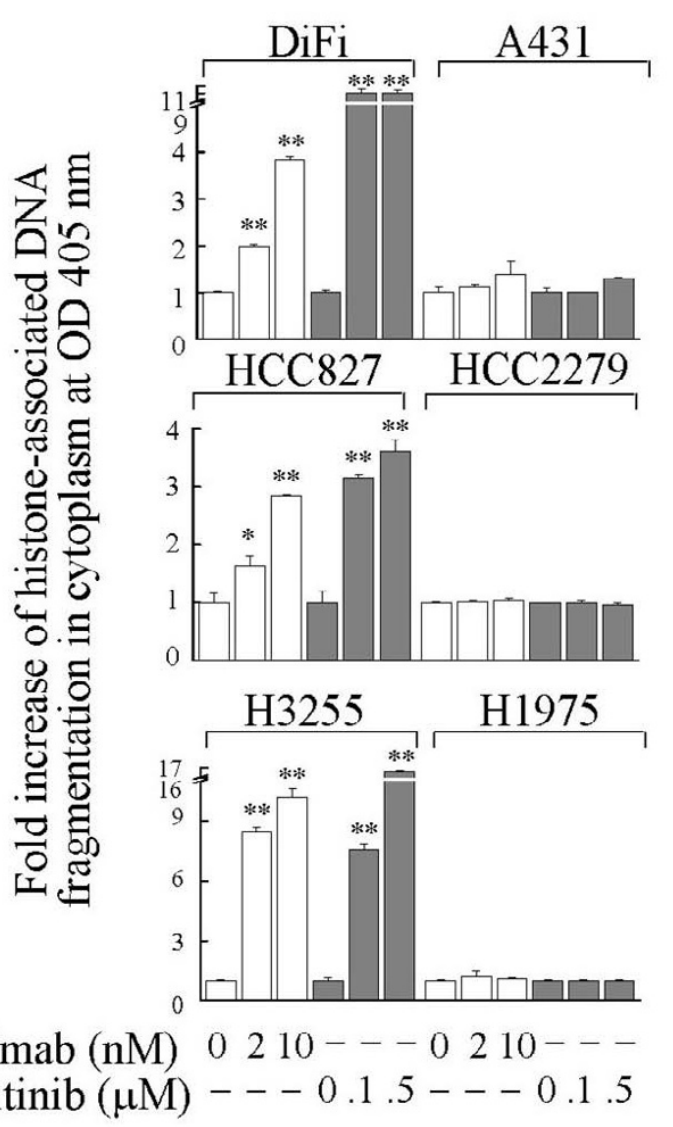
Cetuximab (nM) $0210---0210---$ Gefitinib $(\mu \mathrm{M})---0.1 .5---0.1 .5$

under the treatment condition consisting of $0.5 \%$ FBS in culture medium. As expected, HCC2279 and H1975 cells showed modest or poor anti-proliferative responses to the treatments, with no apoptosis detected in these cell lines with either treatment.

\section{Lack of consistency of changes in phosphorylation levels of} EGFR and common EGFR substrates in association with positive response to cetuximab and gefitinib treatment Following demonstration of their responses to cetuximab and gefitinib treatment, we next used this group of cell lines to assess the levels of association between growth inhibition response after treatment with cetuximab or gefitinib and the changes in phosphorylation levels of EGFR and common EGFR substrates. Overnight incubation with cetuximab downregulated total EGFR contents by various degrees in all cell lines, except A431 cells (Fig. 4a). The extent of EGFR downregulation was mostly evi-

b
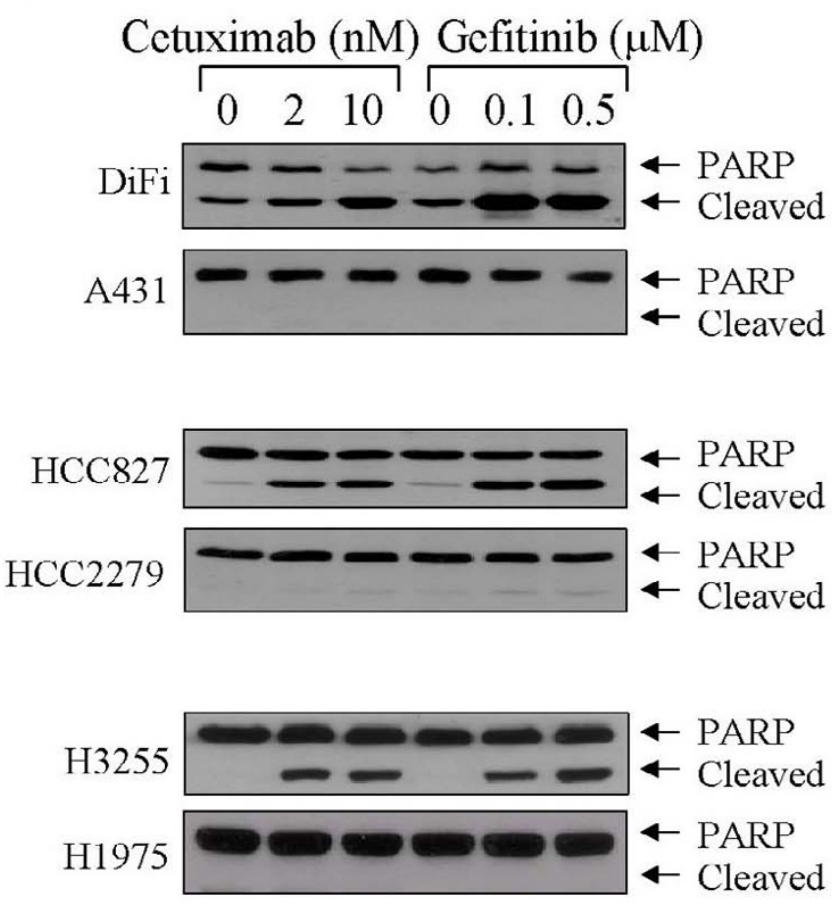

\section{Figure 3}

Induction of apoptosis in cancer cells with wild-type EGFR or tyrosine kinase domain-mutated EGFR by cetuximab and gefitinib. Cells from each line were left untreated or were treated with vehicle (DMSO), $5 \mathrm{nM}$ cetuximab, or $0.5 \mu \mathrm{M}$ gefitinib in a medium containing $0.5 \%$ FBS. After 16 hours of treatment, the cells were harvested and lysed for quantitative apoptosis measurement by (a) an enzyme-linked immunosorbent assay, as described in the Methods section, and (b) Western blot analysis with anti-PARP antibodies. $* \mathrm{P}<0.05, * * \mathrm{P}<0.01$ compared with corresponding controls. 
dent in DiFi, H3255, and H1975 cells, indicating that the extent of EGFR downregulation by cetuximab is unrelated to the coding status of the EGFR sequence. Of interest, gefitinib also led to decreased EGFR content in some cell lines (e.g., DiFi and H3255), which was unexpected of a TKI. The degree to which EGFR phosphorylation was inhibited (relative to the controls) also varied. Under comparable experimental doses and treatment conditions, cetuximab was more effective than gefitinib in inhibiting EGFR phosphorylation in HCC827, H3255, and H1975 cells, but gefitinib was more effective than cetuximab in DiFi, A431, and HCC2279 cells. In particular, cetuximab downregulated EGFR levels and inhibited EGFR phosphorylation remarkably more than did gefitinib in H1975 cells; however, cetuximab was only slightly more effective than gefitinib at inhibiting cell proliferation in H1975 cells (Fig. 2), suggesting that the levels of EGFR downregulation or inhibition of phosphorylation after cetuximab and gefitinib treatment are not consistently correlated with positive responses in all cell lines.

ERK1/2, Akt, and STAT3 are three EGFR downstream signal mediators that are commonly evaluated after EGFRtargeted therapy. Figure 4b shows the changes in their levels of activation-specific phosphorylation after treatment of the cells with cetuximab or gefitinib. Despite an overall decrease in ERK1/2 and Akt phosphorylation levels after either treatment in all cell lines except H1975, the degree of ERK1/2 and Akt phosphorylation inhibition varied and could not be quantitatively associated with the extent of cellular responses to the treatment (Figs. 2 and 3). For example, HCC827 cells were far more responsive than HCC2279 cells to cetuximab- or gefitinib-induced growth inhibition and apoptosis, but the patterns of change in their ERK1/2 and Akt phosphorylation levels were similar. Nevertheless, despite the fact that both gefitinib and cetuximab induced apoptosis in DiFi and H3255 cells, gefitinib inhibited ERK1/2 phosphorylation in DiFi cells only modestly compared with cetuximab, but gefitinib inhibited ERK1/2 in H3255 cells far stronger than did cetuximab. Furthermore, gefitinib and cetuximab led to similar levels of Akt phosphorylation inhibition in DiFi cells, but gefitinib was far more effective than cetuximab in H3255 cells. Taken together, these data indicate that the inhibition of ERK and Akt phosphorylation by cetuximab or gefitinib is cell type-dependent.

Even more divergent results were found in the levels of STAT3 phosphorylation after cetuximab and gefitinib treatment: levels of Tyr705-phosphorylated STAT3, which is regulated primarily via the JAK or Src kinase pathway [26], were markedly increased in A431 and H3255 cells; essentially unchanged or modestly increased in HCC827, HCC2279, and H1975 cells; and decreased in DiFi cells. Cell lines with an increased level of Tyr-705-phosphor- ylated STAT3 after treatment had simultaneous decreases in the levels of Ser-727-phosphorylated STAT3, another important regulatory site that is regulated primarily by ERK1/2 or mTOR kinase $[27,28]$. In DiFi cells, cetuximab and gefitinib reduced phosphorylation at both sites but to different degrees. In the remaining cell lines, the effects of treatment on Tyr-705 phosphorylated and Ser-727 phosphorylated STAT3 levels were generally similar. An investigation into the possible mechanisms of increased Tyr705-phosphorylated STAT3 levels in some cell lines is beyond the scope of the current study, but our results indicate that changes in the levels of phosphorylated STAT3 certainly do not consistently reflect cellular responses to cetuximab or gefitinib.

\section{Downregulation of HIF-I $\alpha$ protein as a positive response marker to cetuximab and gefitinib}

HIF- $1 \alpha$ is a well-known transcription factor whose expression is regulated by growth factor- or oncogene-mediated cell signaling via the phosphatidylinositol 3-kinase pathway [15]. Figure 5 shows that, compared with untreated or vehicle-treated cells, the pattern of changes in the levels of HIF- $1 \alpha$ protein generally mirrored that in the activationspecific phosphorylation of Akt (Fig. 4b) but seems to be more closely associated with the responses to cetuximab and gefitinib treatment. All four cell lines that responded well to cetuximab or gefitinib treatment (DiFi, A431, HCC827, and H3255) had marked decreases in HIF-1 $\alpha$ levels. The patterns of these responses were generally similar among the four cell lines, except that gefitinib induced a higher level of HIF- $1 \alpha$ inhibition than did cetuximab. In contrast, in the remaining two cell lines that failed to show an appreciable growth inhibition response to cetuximab and gefitinib treatment, the HIF-1 $\alpha$ level did not decrease. These results suggest that HIF- $1 \alpha$ is a good indicator of cellular response to EGFR-targeted therapy.

To provide experimental evidence supporting a critical role of HIF-1 $1 \alpha$ downregulation in mediating cellular responses to EGFR-targeted therapy, we introduced a HIF$1 \alpha$ mutant (HIF- $1 \alpha / \Delta$ ODD) in A431 cells. In the HIF- $1 \alpha /$ $\triangle$ ODD mutant, the oxygen-dependent degradation (ODD) domain of HIF-1 $\alpha$ was removed and therefore the mutant became insensitive to VHL ubiquitin ligase-mediated proteasomal degradation, rendering the expressed truncated protein stable in normoxia [29]. After neomycin selection, pooled A431 transfectant cells were obtained and their response to cetuximab was compared with that of control-vector transfected cells. Figure 6a shows that the level of HIF- $1 \alpha / \Delta$ ODD was minimally affected by cetuximab, whereas the level of wild-type HIF-1 $\alpha$ was decreased in A431neo and, to a lesser degree, in A431/ HIF- $1 \alpha / \Delta$ ODD cells. Importantly, A431/HIF-1 $\alpha / \Delta$ ODD cells remained as sensitive to cetuximab-induced inhibition of ERK and Akt as A431neo cells, as shown by 
a

\section{EGFR EGFR-p}

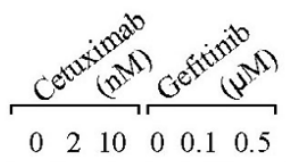

DiFi

$\begin{array}{lllllll}\text { Fold changes: } & 1 & 0.7 & 0.5 & 1 & 0.8 & 0.4\end{array}$

A431

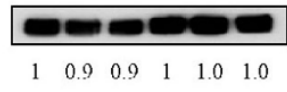

$\mathrm{HCC} 827$

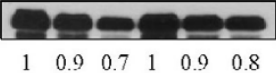

$\mathrm{HCC} 2279$

$\begin{array}{llllll}0.9 & 0.7 & 1 & 0.9 & 0.8\end{array}$
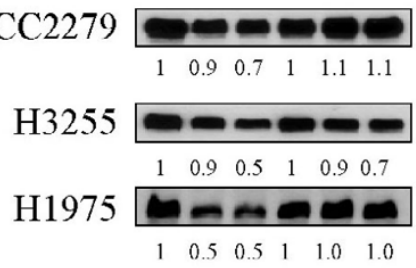

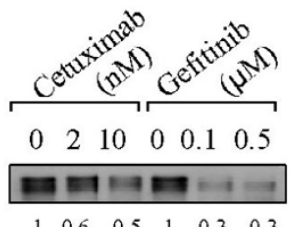

$\begin{array}{llllll}1 & 0.6 & 0.5 & 1 & 0.3 & 0.3\end{array}$
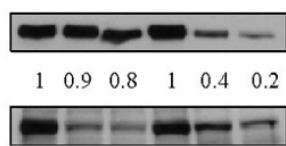

$\begin{array}{llllll}1 & 0.3 & 0.2 & 1 & 0.5 & 0.4\end{array}$
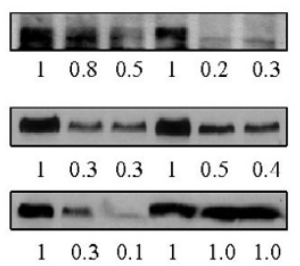

\section{$\beta$-Actin}

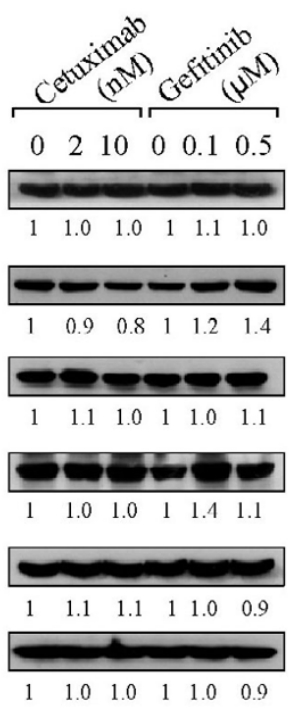

b

ERK2

ERK1/2 (T202/Y204-p)

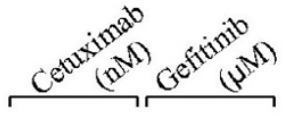

$\begin{array}{llllll}0 & 2 & 10 & 0 & 0.1 & 0.5\end{array}$

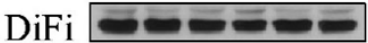
$\begin{array}{lllllll}\text { Fold changes: } & 1 & 1.0 & 0.9 & 1 & 1.2 & 1.1\end{array}$

A431
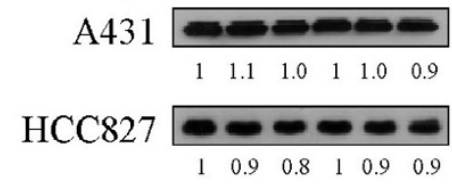

HCC2279

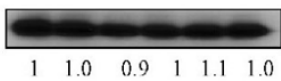

H3255

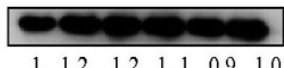

H1975

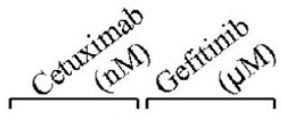

$\begin{array}{llllll}0 & 2 & 10 & 0 & 0.1 & 0.5\end{array}$

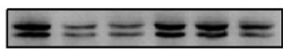

$\begin{array}{llllll}1 & 0.4 & 0.5 & 1 & 1.0 & 0.7\end{array}$
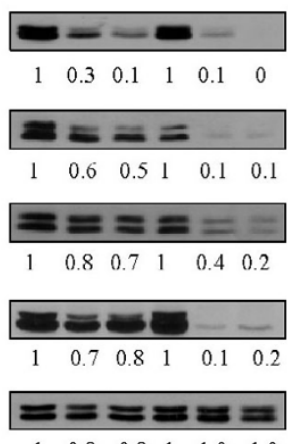

Akt (S473-p)

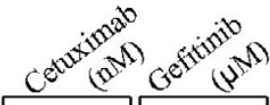

$\begin{array}{llllll}0 & 2 & 10 & 0 & 0.1 & 0.5\end{array}$

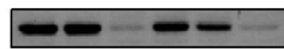

$\begin{array}{llllll}1 & 1.0 & 0.1 & 1 & 0.7 & 0.1\end{array}$
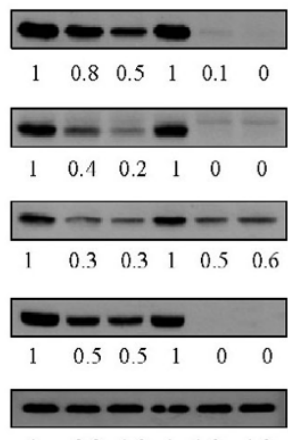

STAT3

(Y705-p)

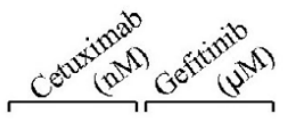

$\begin{array}{llllll}0 & 2 & 10 & 0 & 0.1 & 0.5\end{array}$

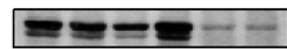

$\begin{array}{llllll}1 & 0.9 & 0.7 & 1 & 0.2 & 0.2\end{array}$

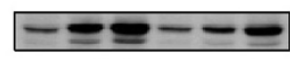

$\begin{array}{llllll}1 & 2.5 & 3.3 & 1 & 1.6 & 3.0\end{array}$
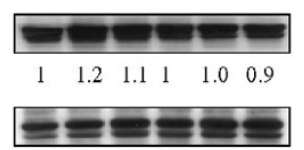

$\begin{array}{llllll}1 & 1.2 & 1.4 & 1 & 1.1 & 1.2\end{array}$
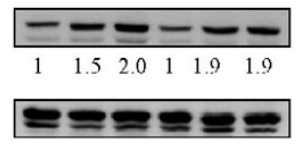

$\begin{array}{lllllll}1 & 1.0 & 1.1 & 1 & 1.0 & 1.0\end{array}$
STAT3

(T727-p)

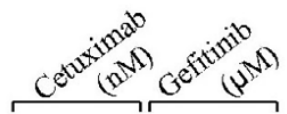

$\begin{array}{llllll}0 & 2 & 10 & 0 & 0.1 & 0.5\end{array}$

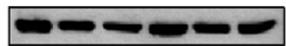

$\begin{array}{llllll}1 & 0.8 & 0.6 & 1 & 0.8 & 0.8\end{array}$

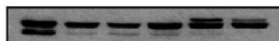

$\begin{array}{llllll}1 & 0.7 & 0.4 & 1 & 0.7 & 0.5\end{array}$

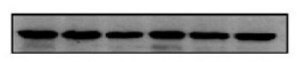

$\begin{array}{llllll}1 & 1.0 & 0.7 & 1 & 0.9 & 0.8\end{array}$

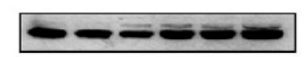

$\begin{array}{llllll}1 & 0.8 & 0.6 & 1 & 1.0 & 1.0\end{array}$
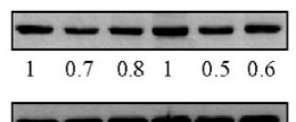

$\begin{array}{llllll}1 & 1.0 & 1.1 & 1 & 0.9 & 0.9\end{array}$

\section{Figure 4}

Effects of cetuximab and gefitinib treatment on the levels of total and phosphorylated EGFR and EGFR substrates in cell lines with wild-type and mutated EGFR. Cells from the indicated lines were simultaneously switched to a culture medium containing $0.5 \% \mathrm{FBS}$ and were either left untreated or treated with cetuximab $(2$ and $10 \mathrm{nM})$, vehicle, or gefitinib $(0.1$ and $0.5 \mu \mathrm{M})$ overnight ( 16 hours). A master medium containing either cetuximab or gefitinib was used in all cell lines. After treatment, the cells were lysed, and equal amounts of cell lysates were subjected to Western blot analysis using antibodies directed against total and phosphorylated EGFR (Y-1068) (a) and antibodies directed against phosphorylated ERK, Akt, and STAT3 as indicated (b). The levels of $\beta$-actin and total ERK served as internal controls for equal protein loading in each lane in (a) and (b), respectively. The numeric values under each gel were derived from a densitometric analysis of the signals. 


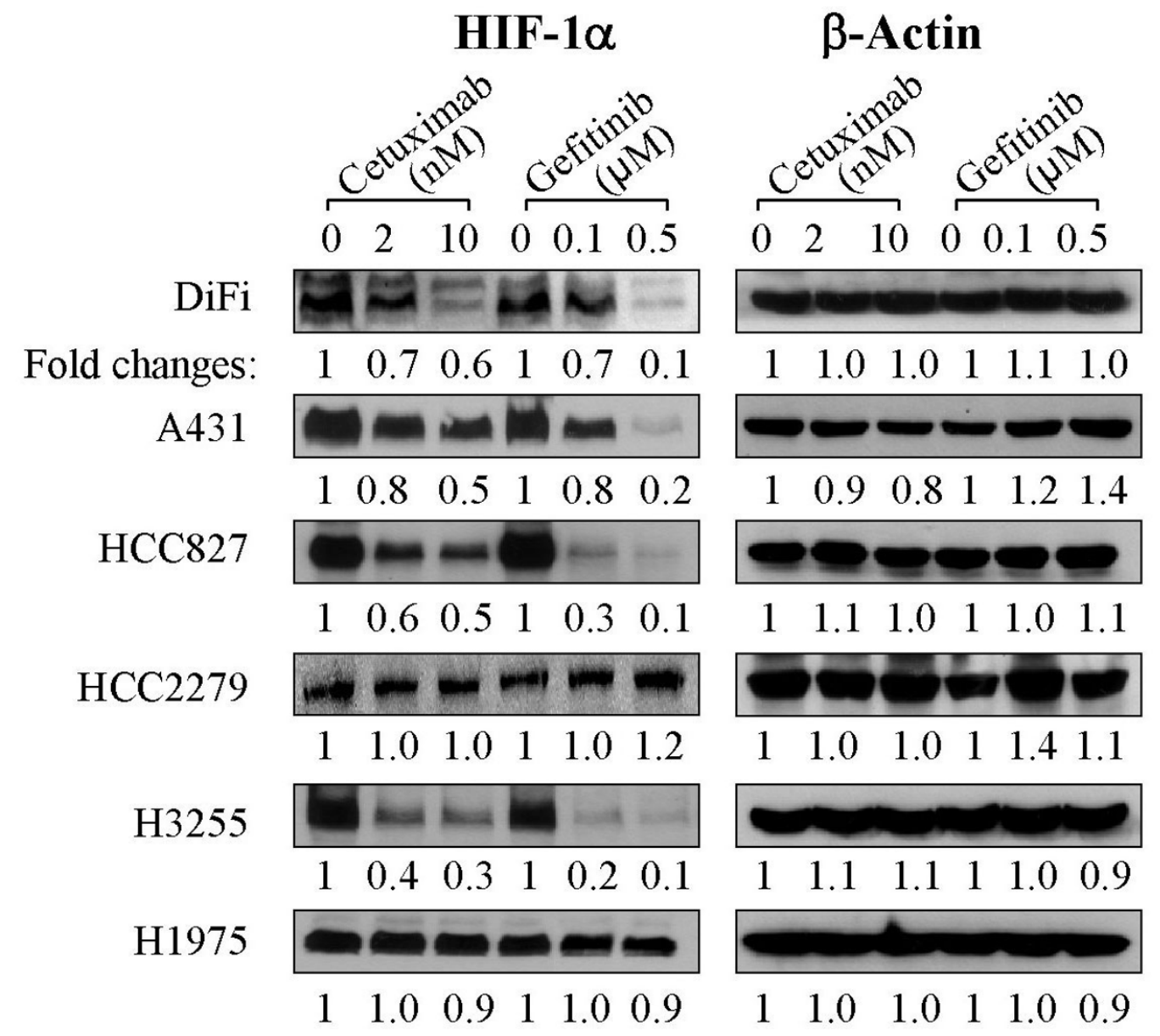

Figure 5

Downregulation of HIF-I $\alpha$ protein levels in cell lines with wild-type or mutated EGFR after treatment with cetuximab or gefitinib. Cells from the indicated cell lines were treated with cetuximab or gefitinib overnight as described in Figure 4. After treatment, the cells were lysed, and equal amounts of cell lysates were subjected to Western blot analysis using antibodies directed against HIF-I $\alpha$, as indicated. The level of $\beta$-actin served as the internal control for equal protein loading in each lane. The numeric values shown under each gel were derived from a densitometric analysis of the signals.

decreased levels of activation-specific phosphorylation in the two molecules. However, the A431/HIF-1 $\alpha / \Delta$ ODD cells were considerably more resistant to cetuximabinduced growth inhibition, as measured by an MTT assay (Fig. 6b). Clonogenic survival assays showed that A431/ HIF- $1 \alpha / \Delta$ ODD had markedly more surviving colonies when cultured in the presence of cetuximab than did untreated A431neo cells, indicating that constitutive expression of HIF- $1 \alpha$ can indeed render cells resistant to cetuximab treatment (Fig. 6c).

\section{Discussion}

Identification of appropriate markers that dependably mirror the responses of cancer cells to EGFR-targeted therapy is a clinically important undertaking. In this study, we used a group of cancer cell lines with either overexpressed or tyrosine kinase domain-mutated ( $\triangle \mathrm{E} 746-\mathrm{A} 750$ or L858R) EGFR to assess their responsiveness to cetuximab and gefitinib treatment and to evaluate HIF-1 $\alpha$ as novel molecular marker for the therapeutic responses of the cancer cells to EGFR-targeted therapy. We found that the posttreatment decrease in the HIF-1 $\alpha$ protein level better correlated with the cellular response than did the decreases in the total or phosphorylated EGFR and phosphorylated EGFR downstream substrate levels (ERK, Akt, and STAT3) in cancer cells with wild-type or tyrosine kinas domainmutated EGFR. This observation was further confirmed by experimental elevation of the HIF-1 $\alpha$ level in the A431 cells, which conferred marked resistance to cetuximab treatment on A431 cells, without affecting cellular sensi- 
a

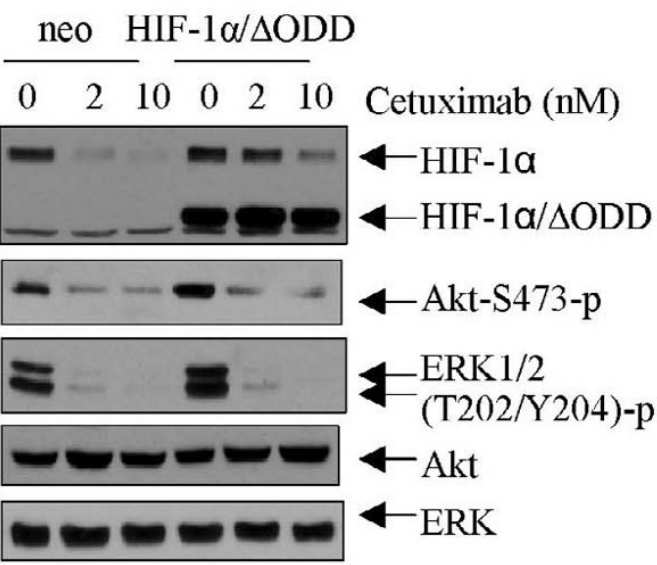

C

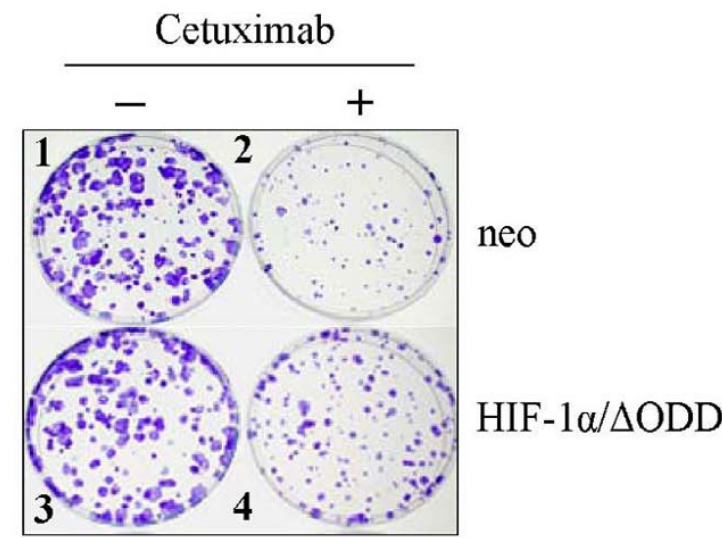

$\mathrm{b}$
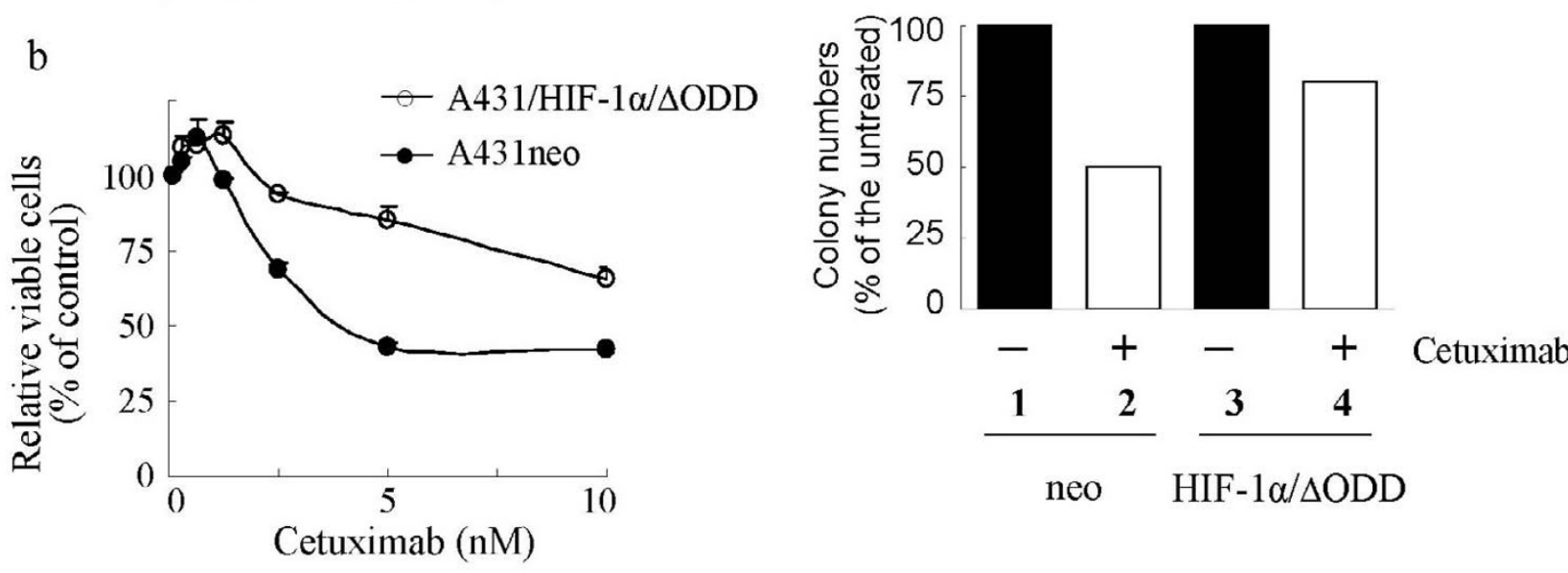

Figure 6

Expression of HIF-I $\alpha / \Delta$ ODD mutant leads to cellular resistance to cetuximab without affecting cellular sensitivity to cetuximab-induced inhibition of EGFR signaling. (a) A43I neo and A43I/HIF-I $\alpha / \Delta O D D$ cells were treated as indicated for I6 hours (overnight). Cell lysates were prepared and subjected to Western blot analysis with the indicated antibodies. (b) Cells were left untreated or treated with the indicated concentrations of cetuximab in culture with $0.5 \%$ FBS for 5 days. Relative cell numbers were measured by the MTT assay and are presented as a percentage of the untreated control. (c) A43 Ineo and A43I/ HIF-I $\alpha / \Delta O D D$ cells ( 300 cells/dish) were cultured, with or without cetuximab $(2 \mathrm{nM})$, for 9 days. After treatment, cells were fixed and the colonies were counted, as described in the Methods section.

tivity to cetuximab-induced inhibition of ERK and Akt activation-specific phosphorylation levels.

It is rational to choose HIF- $1 \alpha$ as a novel response marker to EGFR-targeted therapy. First, functioning as an inducible binding partner of an important transcription factor regulating many genes involved in tumorigenesis and cancer progression, HIF- $1 \alpha$ is an end downstream effector molecule common to the ERK-, Akt-, and STAT3-mediated signal transduction pathways. Because it represents a convergent point of these pathways, HIF- $1 \alpha$ is more critical than ERK, Akt, or STAT3 alone in the relay of cell signaling into the nucleus following activation of EGFR [15]. Second, EGFR inhibitors are currently approved and being tested only in solid tumors. Many solid tumors are hypoxic and contain high levels of HIF-1 $\alpha$ as a result of increased protein stability; this makes detection of a posttreatment decrease of HIF-1 $\alpha$ relatively easy with histological examination of biopsied tumor specimens or by molecular imaging of HIF- $1 \alpha$ level changes in the tumors of patients [30,31]. Our data strongly suggest the value of a retrospective review of the correlation of HIF- $1 \alpha$ in tumors with responses of the patients to the EGFR-targeted therapies.

In our study, the cellular responses to treatment with cetuximab and gefitinib are consistent with the previous findings of others that mutations in the EGFR tyrosine kinase domain renders the cancer cells sensitive to very low doses of small-molecule TKIs, with the mutations having no effect on cellular sensitivity to monoclonal antibody treatment [24]. However, our data also suggest 
that the mutation itself is not a sole determinant of apoptosis induction upon EGFR-targeted therapy, because our data show that apoptosis can be induced in cells with either wild-type EGFR (DiFi cells) or the mutated EGFRs (H3255 and HCC827 cells) by either gefitinib or cetuximab treatment. Despite an enhanced sensitivity to low doses of TKI, the maximal therapeutic responses to gefitinib and cetuximab in the EGFR-mutated cells were similar overall when the treatment timing and doses of either agent were appropriate, leading to sufficient inhibition of EGFR kinase activity. Two EGFR-mutated cell lines (HCC827 and H3255) that underwent apoptosis upon gefitinib treatment responded to cetuximab treatment with similar ultimate results (apoptosis), and two other EGFR-mutated cell lines (HCC2279 and H1975) that responded poorly or moderately to gefitinib treatment showed unfavorable responses to cetuximab as well. In particular, H1975 cells contain a second mutation (T790M) reported to be linked to gefitinib resistance [25], but we found that these cells also responded poorly to cetuximab.

It has been proposed that mutations in the tyrosine kinase domain of EGFR cause repositioning of several critical residues surrounding the ATP-binding cleft of the tyrosine kinase domain; this repositioning stabilizes the interactions between the ATP-binding site and reversible inhibitors such as gefitinib $[10,11]$. Because of their strong interaction, the mutated EGFR can be readily inhibited by TKI with low doses that were usually insufficient to inhibit wild-type EGFR. This speculation is consistent with emerging evidence showing that irreversible EGFR inhibitors decrease the receptor kinase more efficiently than do reversible inhibitors [32]. There is an important caveat, however: although the mutations in the EGFR tyrosine kinase domain result in an enhanced cellular sensitivity to TKI treatment, the mutated EGFR still requires a ligand for receptor activation $[10,11,33]$. This requirement of ligand binding suggests that EGFR-mutated cells and EGFR wildtype cells should be equally susceptible to cetuximabmediated receptor blockade. Nevertheless, our data show that cetuximab can indiscriminatingly downregulate EGFR levels in cell lines with either wild-type or mutated EGFR.

Of note, our results on the response of H3255 cells to cetuximab differ from those of another recent study, which reported that H3255 cells were substantially less responsive to cetuximab than to gefitinib [24]. In our study, this was true for only a short time period (6-8 hours) of exposure to cetuximab; cell death was not initially evident in cetuximab-treated cells, whereas gefitinib induced massive cell death that was microscopically visible and measurable via biochemical assays. After the cells had been cultured overnight, however, we found clear evi- dence of apoptosis in cells treated with cetuximab, both in the level of histone-associated DNA fragments in the cytoplasm and in the cleavage of PARP. By 72 hours, both agents had markedly decreased H3255 cell survival. The time course difference in inducing apoptosis between cetuximab and gefitinib may be explained by the nature of their different working mechanisms: EGFR inhibition induced by cetuximab may require a longer time to effectively block or downregulate EGFR than the time required by gefitinib to shut down kinase activity through competition with ATP binding. In addition, cetuximab is highly specific to EGFR, whereas TKIs are relatively less specific; inhibition of additional targets besides EGFR by gefitinib may also contribute to a faster cellular effect than that of the monoclonal antibody.

\section{Conclusion}

Our data suggest that a decrease in HIF- $1 \alpha$ levels is indicative of positive responses to EGFR-targeted therapy of cancer cells with either wild-type or tyrosine kinase domain-mutated EGFR. Genetic aberrations causing an exclusive dependence of cancer cells on the EGFR-mediated cell signaling (i.e., oncogenic addiction), which may be found in cancer cells with either wild-type or tyrosine kinase domain-mutated EGFR, are likely the causes or the molecular determinants of the apoptotic responses of cells to EGFR-targeted therapy. The use of HIF-1 $\alpha$ as an indicator of tumor response to EGFR-targeted therapy should be further investigated in preclinical studies and in the clinical setting.

\section{Methods \\ Materials}

Cetuximab and gefitinib were gifts from ImClone Systems, Inc. (New York, NY, USA) and AstraZeneca (Wilmington, DE, USA), respectively. All other materials were purchased from Sigma-Aldrich (St. Louis, MO, USA) unless otherwise specified.

\section{Cell lines and culture}

A431 human vulvar squamous carcinoma cells and DiFi colorectal adenocarcinoma cells were described previously [34-37]. HCC827, HCC2279, H3255, and H1975 human NSCLC cell lines were kindly provided by Dr. John Minna of The University of Texas Southwestern Medical Center (Dallas, TX, USA) through Dr. Jonathan M. Kurie of The University of Texas M. D. Anderson Cancer Center (Houston, TX, USA). All cell lines were grown and maintained in Dulbecco's modified Eagle's medium or Ham's F12 medium supplemented with 10\% fetal bovine serum (FBS), $2 \mathrm{mM}$ glutamine, $100 \mathrm{U} / \mathrm{mL}$ penicillin, and $100 \mu \mathrm{g} /$ $\mathrm{mL}$ streptomycin and incubated in a humidified atmosphere $\left(95 \%\right.$ air and $\left.5 \% \mathrm{CO}_{2}\right)$ at $37^{\circ} \mathrm{C}$. 


\section{RNA extraction, cDNA synthesis, polymerase chain reaction, and EGFR sequencing}

Total RNA was extracted from the cell lines using a modified chloroform/phenol procedure (Trizol; InvitrogenLife Technologies, Gaithersburg, MD, USA). First-strand cDNA of the intracellular domain of EGFR was generated using reverse transcriptase (Roche Diagnostics Corp., Indianapolis, IN, USA) and amplified by polymerase chain reaction (PCR) using the Expand high-fidelity PCR system (Roche Diagnostics) with the following primer pair: forward (2137-2157 bp), 5'-AAAAAGATCAAAGTGCTGGGC-3'; and reverse (3643-3625 bp), 5'-CCTCCGTGGTCATGCTCC-3'. PCR products were purified by precipitation with alcohol, and sequences were analyzed by an automated DNA sequence analyzer using the same primers.

\section{Western blot analysis and blotting antibodies}

Cultured cells were harvested with a rubber scraper and washed twice with cold phosphate-buffered saline. Cell pellets were lysed and kept on ice for at least 10 minutes with a buffer containing $50 \mathrm{mM}$ Tris (pH 7.4), $150 \mathrm{mM}$ $\mathrm{NaCl}, 0.5 \%$ Nonidet P-40, $50 \mathrm{mM} \mathrm{NaF}, 1 \mathrm{mM} \mathrm{Na}_{3} \mathrm{VO}_{4}, 1$ mM phenylmethylsulfonylfluoride, $25 \mu \mathrm{g} / \mathrm{mL}$ leupeptin, and $25 \mu \mathrm{g} / \mathrm{mL}$ aprotinin. The lysates were cleared by centrifugation, and the supernatants were collected. Equal amounts of lysate protein were separated by sodium dodecyl sulfate-polyacrylamide gel electrophoresis, and Western blot analyses were performed with various specific primary antibodies. The antibodies directed against total and Y1068-phosphorylated EGFR, HER2, total and S473-phosphorylated Akt, T202/Y204-phosphorylated ERK, and PARP were obtained from Cell Signaling Technology, Inc. (Beverly, MA, USA). Antibodies directed against ERK and HER3 were obtained from Santa Cruz Biotechnology, Inc. (Santa Cruz, CA, USA). Specific signals were visualized using an enhanced chemiluminescence detection kit (Amersham, Arlington Heights, IL, USA).

\section{Cell proliferation and survival assays}

Time-dependent cell responses to treatments were determined by counting cells. After the various treatments, cells were harvested by trypsinization and counted in a Coulter counter. Dose-dependent cell responses to treatment were determined by MTT [3-(4,5-dimethylthiazol-2-yl)-2, 5diphenyltetrazolium bromide] colorimetric assays. After treatment, cells were incubated for 2 hours at $37^{\circ} \mathrm{C}$ in a $\mathrm{CO}_{2}$ incubator with $10 \mathrm{mg} / \mathrm{mL}$ MTT (50 $\mu \mathrm{L} /$ well). The cells were then lysed with a lysis buffer ( $500 \mu \mathrm{L} /$ well $)$ containing 20\% sodium dodecyl sulfate in dimethyl formamide $/ \mathrm{H}_{2} \mathrm{O}(1: 1, \mathrm{v} / \mathrm{v})(\mathrm{pH} 4.7)$ at $37^{\circ} \mathrm{C}$ for at least 6 hours. The relative survival of untreated and treated cells was determined by measuring the optical density of cell lysates at a wavelength of $570 \mathrm{~nm}$. Cell viability was expressed as a percentage and calculated as the optical density of the treated cells relative to that of the corresponding control or untreated cells.

\section{Apoptosis assays}

Apoptosis was measured by detecting proteolytic cleavage of PARP using Western blot analysis and by quantifying cytoplasmic levels of histone-associated DNA fragments (mononucleosomes and oligonucleosomes) using an enzyme-linked immunosorbent assay kit (Roche Diagnostics), as we previously reported $[38,39]$.

\section{HIF-I $\alpha$ construct and transfection}

The pcDNA3 expression construct containing the HIF-1 $\alpha$ / $\Delta$ ODD mutant was kindly provided by Dr. L. Eric Huang (University of Utah School of Medicine, Salt Lake City, UT, USA). Transient transfection of the construct was performed with lipofectamine 2000 (Invitrogen, Carlsbad, CA, USA), following the instructions provided by the manufacturer (Roche Diagnostics).

\section{Monolayer clonogenic assays}

Exponentially growing cells were collected from monolayer culture by trypsinization and plated at a low density. Cells were allowed to adhere overnight prior to the addition of 2 nM cetuximab in 10\% FBS culture medium for 9 days. Colonies were fixed in $1 \%$ crystal violet blue $(\mathrm{w} / \mathrm{v})$ in $100 \%$ methanol for 30 minutes. Colonies estimated to be larger than 50 cells were counted, and survival was calculated relative to the number of untreated controls.

\section{Abbreviations}

EGFR, epidermal growth factor receptor; HER, human EGF receptor family; HIF-1 $\alpha$, hypoxia-inducible growth factor-1 $\alpha ; \Delta$ ODD, oxygen-dependent domain deletion mutant of HIF-1 $\alpha$; ERK, extracellular signaling-related kinase; TKI, small-molecule tyrosine kinase inhibitors; NSCLC, non-small cell lung cancers.

\section{Competing interests}

The author(s) declare that they have no competing interests.

\section{Authors' contributions}

$\mathrm{YL}, \mathrm{KL}$, and XL performed experiments and interpreted data; the authors' contributions to this research are reflected in the order shown. ZF supervised all aspects of this research and prepared the manuscript. All authors read and approved the final manuscript.

\section{Acknowledgements}

This study was supported in part by the National Cancer Institute Cancer Center Support Grant P30 CA 16672. We thank Drs. John Minna and Jonathan M. Kurie for providing the EGFR tyrosine domain-mutated NSCLC cell lines and Dr. L. Eric Huang for the HIF-I $\alpha / \Delta$ ODD mutant construct. 


\section{References}

I. Mendelsohn J, Baselga J: The EGF receptor family as targets for cancer therapy. Oncogene 2000, 19:6550-6565.

2. Arteaga CL: Overview of epidermal growth factor receptor biology and its role as a therapeutic target in human neoplasia. Semin Oncol 2002, 29:3-9.

3. Grunwald V, Hidalgo M: Developing inhibitors of the epidermal growth factor receptor for cancer treatment. J Natl Cancer Inst 2003, 95:85 I-867.

4. Janne PA, Engelman JA, Johnson BE: Epidermal growth factor receptor mutations in non-small-cell lung cancer: implications for treatment and tumor biology. J Clin Oncol 2005, 23:3227-3234

5. Cunningham D, Humblet Y, Siena S, Khayat D, Bleiberg H, Santoro A, Bets D, Mueser M, Harstrick A, Verslype C, Chau I, Van Cutsem E: Cetuximab monotherapy and cetuximab plus irinotecan in irinotecan-refractory metastatic colorectal cancer. $N$ Engl J Med 2004, 35 I:337-345.

6. Fukuoka M, Yano S, Giaccone G, Tamura T, Nakagawa K, Douillard JY, Nishiwaki Y, Vansteenkiste J, Kudoh S, Rischin D, Eek R, Horai T, Noda K, Takata I, Smit E, Averbuch S, Macleod A, Feyereislova A, Dong RP, Baselga J: Multi-institutional randomized phase II trial of gefitinib for previously treated patients with advanced non-small-cell lung cancer. J Clin Oncol 2003, 2 I:2237-2246.

7. Kris MG, Natale RB, Herbst RS, Lynch TJ Jr., Prager D, Belani CP Schiller JH, Kelly K, Spiridonidis H, Sandler A, Albain KS, Cella D, Wolf MK, Averbuch SD, Ochs J], Kay AC: Efficacy of gefitinib, an inhibitor of the epidermal growth factor receptor tyrosine kinase, in symptomatic patients with non-small cell lung cancer: a randomized trial. JAMA 2003, 290:2I 49-2I 58.

8. Giaccone G, Herbst RS, Manegold C, Scagliotti G, Rosell R, Miller V, Natale RB, Schiller JH, Von Pawel J, Pluzanska A, Gatzemeier U Grous J, Ochs JS, Averbuch SD, Wolf MK, Rennie P, Fandi A, Johnson $\mathrm{DH}$ : Gefitinib in combination with gemcitabine and cisplatin in advanced non-small-cell lung cancer: a phase III trial-INTACT I. J Clin Oncol 2004, 22:777-784.

9. Herbst RS, Giaccone G, Schiller JH, Natale RB, Miller V, Manegold C, Scagliotti G, Rosell R, Oliff I, Reeves JA, Wolf MK, Krebs AD, Averbuch SD, Ochs JS, Grous J, Fandi A, Johnson DH: Gefitinib in combination with paclitaxel and carboplatin in advanced nonsmall-cell lung cancer: a phase III trial--INTACT 2. J Clin Oncol 2004, 22:785-794.

10. Lynch TJ, Bell DW, Sordella R, Gurubhagavatula S, Okimoto RA, Brannigan BW, Harris PL, Haserlat SM, Supko JG, Haluska FG, Louis DN, Christiani DC, Settleman J, Haber DA: Activating mutations in the epidermal growth factor receptor underlying responsiveness of non-small-cell lung cancer to gefitinib. $N$ Engl $\mathrm{Jed}$ 2004, 350:2129-2I39.

II. Paez JG, Janne PA, Lee JC, Tracy S, Greulich H, Gabriel S, Herman P Kaye FJ, Lindeman N, Boggon TJ, Naoki K, Sasaki H, Fujii Y, Eck MJ, Sellers WR, Johnson BE, Meyerson M: EGFR mutations in lung cancer: correlation with clinical response to gefitinib therapy. Science 2004, 304:|497-I500.

12. Pao W, Miller V, Zakowski M, Doherty J, Politi K, Sarkaria I, Singh B Heelan R, Rusch V, Fulton L, Mardis E, Kupfer D, Wilson R, Kris M, Varmus $H$ : EGF receptor gene mutations are common in lung cancers from "never smokers" and are associated with sensitivity of tumors to gefitinib and erlotinib. Proc Natl Acad Sci U S A 2004, I 0 I: | 3306-|33| I.

13. Luwor RB, Lu Y, Li X, Mendelsohn J, Fan Z: The antiepidermal growth factor receptor monoclonal antibody cetuximab/ C225 reduces hypoxia-inducible factor-I alpha, leading to transcriptional inhibition of vascular endothelial growth factor expression. Oncogene 2005, 24:4433-444I.

14. Pore N, Jiang Z, Gupta A, Cerniglia G, Kao GD, Maity A: EGFR tyrosine kinase inhibitors decrease VEGF expression by both hypoxia-inducible factor (HIF)-I-independent and HIF-Idependent mechanisms. Cancer Res 2006, 66:3197-3204.

15. Semenza GL: Targeting HIF-I for cancer therapy. Nat Rev Cancer 2003, 3:721-732

16. Harris AL: Hypoxia--a key regulatory factor in tumour growth. Nat Rev Cancer 2002, 2:38-47.

17. Zelzer E, Levy Y, Kahana C, Shilo BZ, Rubinstein M, Cohen B: Insulin induces transcription of target genes through the hypoxiainducible factor HIF-Ialpha/ARNT. EMBO J I998, | 7:5085-5094.
18. Zhong H, Chiles K, Feldser D, Laughner E, Hanrahan C, Georgescu MM, Simons JW, Semenza GL: Modulation of hypoxia-inducible factor Ialpha expression by the epidermal growth factor/ phosphatidylinositol 3-kinase/PTEN/AKT/FRAP pathway in human prostate cancer cells: implications for tumor angiogenesis and therapeutics. Cancer Res 2000, 60:I54I-I545.

19. Blancher C, Moore JW, Robertson N, Harris AL: Effects of ras and von Hippel-Lindau (VHL) gene mutations on hypoxia-inducible factor (HIF)-I alpha, HIF-2alpha, and vascular endothelial growth factor expression and their regulation by the phosphatidylinositol 3'-kinase/Akt signaling pathway. Cancer Res 2001, 61:7349-7355.

20. Treins C, Giorgetti-Peraldi S, Murdaca J, Semenza GL, Van Obberghen E: Insulin stimulates hypoxia-inducible factor I through a phosphatidylinositol 3-kinase/target of rapamycindependent signaling pathway. I Biol Chem 2002, 277:27975-2798I.

2I. Fukuda R, Hirota K, Fan F, Jung YD, Ellis LM, Semenza GL: Insulinlike growth factor $I$ induces hypoxia-inducible factor I-mediated vascular endothelial growth factor expression, which is dependent on MAP kinase and phosphatidylinositol 3-kinase signaling in colon cancer cells. J Biol Chem 2002, 277:38205-382II.

22. Minet E, Arnould T, Michel G, Roland I, Mottet D, Raes M, Remacle J, Michiels C: ERK activation upon hypoxia: involvement in HIF. I activation. FEBS Lett 2000, 468:53-58

23. Amann J, Kalyankrishna S, Massion PP, Ohm JE, Girard L, Shigematsu H, Peyton M, Juroske D, Huang Y, Stuart SJ, Kim YH, Pollack JR, Yanagisawa K, Gazdar A, Minna JD, Kurie JM, Carbone DP: Aberrant epidermal growth factor receptor signaling and enhanced sensitivity to EGFR inhibitors in lung cancer. Cancer Res 2005 , 65:226-235

24. Mukohara T, Engelman JA, Hanna NH, Yeap BY, Kobayashi S, Lindeman N, Halmos B, Pearlberg J, Tsuchihashi Z, Cantley LC, Tenen DG, Johnson BE, Janne PA: Differential effects of gefitinib and cetuximab on non-small-cell lung cancers bearing epidermal growth factor receptor mutations. I Natl Cancer Inst 2005, 97:1185-1194.

25. Pao W, Miller VA, Politi KA, Riely G], Somwar R, Zakowski MF, Kris $M G$, Varmus $H$ : Acquired resistance of lung adenocarcinomas to gefitinib or erlotinib is associated with a second mutation in the EGFR kinase domain. PLoS Med 2005, 2:e73.

26. Darnell JE Jr., Kerr IM, Stark GR: Jak-STAT pathways and transcriptional activation in response to IFNs and other extracelIular signaling proteins. Science 1994, 264:|4|5-|42|.

27. Wen Z, Zhong Z, Darnell JE Jr.: Maximal activation of transcription by $S t a t I$ and $S$ tat 3 requires both tyrosine and serine phosphorylation. Cell 1995, 82:24I-250.

28. Yokogami K, Wakisaka S, Avruch J, Reeves SA: Serine phosphorylation and maximal activation of STAT3 during CNTF signaling is mediated by the rapamycin target mTOR. Curr Biol 2000, 10:47-50.

29. Huang LE, Gu J, Schau M, Bunn HF: Regulation of hypoxia-inducible factor I alpha is mediated by an O2-dependent degradation domain via the ubiquitin-proteasome pathway. Proc Nat Acad Sci U S A 1998, 95:7987-7992.

30. Serganova I, Doubrovin M, Vider J, Ponomarev V, Soghomonyan S, Beresten T, Ageyeva L, Serganov A, Cai S, Balatoni J, Blasberg R, Gelovani J: Molecular imaging of temporal dynamics and spatial heterogeneity of hypoxia-inducible factor-I signal transduction activity in tumors in living mice. Cancer Res 2004, 64:6101-6108.

31. Wen B, Burgman P, Zanzonico P, O'donoghue J, Cai S, Finn R, Serganova I, Blasberg R, Gelovani J, Li GC, Ling CC: A preclinical model for noninvasive imaging of hypoxia-induced gene expression; comparison with an exogenous marker of tumor hypoxia. Eur J Nucl Med Mol Imaging 2004, 3 I : I 530- I 538.

32. Baselga J: Why the epidermal growth factor receptor? The rationale for cancer therapy. Oncologist 2002, 7 Suppl 4:2-8.

33. Sordella R, Bell DW, Haber DA, Settleman J: Gefitinib-sensitizing EGFR mutations in lung cancer activate anti-apoptotic pathways. Science 2004, 305: I I63-I I67.

34. Fan Z, Baselga J, Masui H, Mendelsohn J: Antitumor effect of antiepidermal growth factor receptor monoclonal antibodies plus cis-diamminedichloroplatinum on well established A43 I cell xenografts. Cancer Res 1993, 53:4637-4642. 
35. Fan Z, Masui H, Altas I, Mendelsohn J: Blockade of epidermal growth factor receptor function by bivalent and monovalent fragments of $\mathbf{2 2 5}$ anti-epidermal growth factor receptor monoclonal antibodies. Cancer Res 1993, 53:4322-4328.

36. Wu X, Fan Z, Masui H, Rosen N, Mendelsohn J: Apoptosis induced by an anti-epidermal growth factor receptor monoclonal antibody in a human colorectal carcinoma cell line and its delay by insulin. J Clin Invest 1995, 95: I897-1905.

37. Liu B, Fang M, Lu Y, Mendelsohn J, Fan Z: Fibroblast growth factor and insulin-like growth factor differentially modulate the apoptosis and GI arrest induced by anti-epidermal growth factor receptor monoclonal antibody. Oncogene 200I, 20:1913-1922

38. Liu B, Fang M, Schmidt M, Lu Y, Mendelsohn J, Fan Z: Induction of apoptosis and activation of the caspase cascade by anti-EGF receptor monoclonal antibodies in DiFi human colon cancer cells do not involve the c-jun $\mathbf{N}$-terminal kinase activity. $\mathrm{Br} J$ Cancer 2000, 82: | 99|-| 999.

39. Li X, Luwor R, Lu Y, Liang K, Fan Z: Enhancement of antitumor activity of the anti-EGF receptor monoclonal antibody cetuximab/C225 by perifosine in PTEN-deficient cancer cells. Oncogene 2006, 25:525-535.

Publish with Bio Med Central and every scientist can read your work free of charge

"BioMed Central will be the most significant development for disseminating the results of biomedical research in our lifetime. "

Sir Paul Nurse, Cancer Research UK

Your research papers will be:

- available free of charge to the entire biomedical community

- peer reviewed and published immediately upon acceptance

- cited in PubMed and archived on PubMed Central

- yours - you keep the copyright

Submit your manuscript here:

http://www.biomedcentral.com/info/publishing_adv.asp 